\title{
The Quest for Transparency and Accountability: Communicating Responsibly to Stakeholders in Crises
}

\author{
Donyale R. Griffin Padgett ${ }^{1}$, Shuhui Sophy Cheng ${ }^{2} \&$ Vinita Parekh ${ }^{1}$ \\ ${ }^{1}$ Department of Communication, Wayne State University, Detroit, USA \\ ${ }^{2}$ Department of Communication Arts, Chaoyang University of Technology, Taichung, Taiwan \\ Correspondence: Donyale R. Griffin Padgett, Department of Communication, Wayne State University, 515 \\ Manoogian Hall, Detroit, MI 48201, USA. Tel: 1-313-577-3544. E-mail: drpadge@wayne.edu
}

Received: March 11, 2013 Accepted: April 22, 2013 Online Published: June 28, 2013

doi:10.5539/ass.v9n9p31 URL: http://dx.doi.org/10.5539/ass.v9n9p31

\begin{abstract}
As organizations around the world experience crises, they are finding it necessary to craft messages that speak to a more global audience in order to renegotiate social legitimacy by demonstrating ethical leadership in a more global environment. This paper aims at investigating two crisis cases across international borders, including BP's (formerly British Petroleum) massive oil spill in the Gulf of Mexico and Indian-based Satyam Computer Services' near-collapse as a result of corporate fraud. In both cases, crisis response demonstrated a lack of sensitivity to stakeholders, a lack of transparency, and a lack of strategic communication. In this study, we examine the crisis response of company officials in the aftermath of events that had both national and global effects. From the analysis, three general themes emerge: 1) issues of blame and accountability, 2) issue of transparency, and 3) success or failure in crisis response. The cases point to the need for organizational leaders to establish a clear line of communication with stakeholders, so they are better equipped to move beyond the crisis situation. Findings demonstrate that the more we know about how companies translate their role as corporate citizens, particularly in the face of crises, the better we are to determine standards for practice that help to rebuild image and restore legitimacy.
\end{abstract}

Keywords: crisis communication, crisis response strategies, ethics, corporate social responsibility, transparency, accountability

\section{Introduction}

Crisis communication is a burgeoning field, and has received considerable attention with the rise of corporate misconduct cases. We need only to look at Enron, WorldCom, Merrill Lynch, and Martha Stewart to see the crippling effect of mismanaging the truth (Seeger \& Ulmer, 2003; Hearit \& Brown, 2004; Reber \& Gower, 2006; Oles, 2010). In these cases it is important for company leaders to engage with multiple audiences about the nature and severity of their actions. Fortunato (2008) indicates that the crisis event makes it necessary to use crisis response strategies because responsibility for the occurrence is placed on the organization. Transparency and accountability are needed in these cases to explain "the facts of the incident, but also to provide a feeling that steps are being taken to help ensure that a similar incident will never happen again" (Fortunato, 2008, p. 117).

In today's business environment, stakeholders expect to have access to corporate information unrestrictedly. They also demand organizations be held accountable for their business plan and operational goals. According to Silver (2005), stakeholders ask that organizations become more transparent not only "in the numbers they release but also in how they're run" (p. 16). He explains that in an age when nothing is hidden for long, everything depends on trust and transparency. In particular, when a company is struck by a crisis, there is usually much pressure to be open and honest. An organizational dilemma can test the degree to which corporate social responsibility (CSR) is valued. Seeger (1997) points out that organizational crisis almost always bring up basic ethical issues about blame, wrongdoing, cause and responsibility. However, too often, organizations choose to withhold information, remain ambiguous or simply stonewall (Ulmer, Sellnow \& Seeger, 2007). These kinds of responses are not ethically justifiable and have a devastating impact on a company's reputation in terms of profitability and credibility.

As more companies expand their reach across geographic borders it becomes necessary to develop a more global 
framework for corporate social responsibility that demonstrates responsiveness to "multiples cultures, values sets and communicative practices of different nations" (Stohl, Stohl \& Townsley, 2007, p. 34). This paper investigates two crisis cases across international borders, including BP's (formerly British Petroleum) massive oil spill in the Gulf of Mexico and Indian-based Satyam Computer Services' near-collapse as a result of corporate fraud. In both cases, response efforts demonstrate a lack of sensitivity to stakeholders, a lack of transparency, and a lack of strategic communication. Following a crisis, it is natural for stakeholders to take steps to find out who is responsible or culpable for the occurrence.

This study explores the crisis response of company officials in the aftermath of events that engage in stakeholder dialogue and communicate their progress in corporate social responsibility. We examine the degree to which the choices of company officials with regard to transparency and accountability affected the company's image, market share and subsequent recoveries. Finally, we contribute to the discussion on effective crisis management strategies across these socio-cultural contexts.

\section{Background of the Two Cases}

\subsection{Crisis Puts BP in Deep Water}

On April 20, 2010 there was an explosion in the Gulf of Mexico on the Deepwater Horizon, an offshore drilling rig leased by British Petroleum (BP). The explosion killed 11 crewmen and injured 17 others. The sinking of the burning oil rig two days later dumped as much as 4.9 million barrels of oil into the sea before the broken well was capped in mid-July, 2010. It caused one of the worst environmental disasters in the history of the petroleum industry. The U.S. Government strongly blamed BP and called for the oil company to rectify the problem. Within 50 days of the explosion, BP's stock fell by 52\%, going from $\$ 60.57$ on April 20, to $\$ 29.20$ on June 9, 2010. Immediately after the explosion BP's CEO Tony Hayward became engulfed in a firestorm of public ridicule over a series of consecutive missteps that raised ethical concerns about BPs handling of the crisis. These glitches included insensitive comments, too much focus on reducing the number of claims filed and not enough public attention to the tragedy of the accident, initial assessments of the damage that minimized the effect of the spill, and premature promises about the timeline for containment.

This was not the first time the oil giant had been under fire. A series of on-site tragedies in the company's chemical plants were the subject of a 2004 Texas Public Interest Research Group report, which cited BP as number one in accidents in the nation (Elder, 2005). According to Maresh and Williams (2012), this contributed to "an overall perception" that BPs plants were "unsafe and ill-supervised." These incidents heightened stakeholders' concerns about BPs use of safety measures to protect the environment and its commitment to social responsibility.

Ethical issues had already begun to be raised prior to this most recent incident, as Schultz et al. (2012) report, related to "internal concerns on the quality of the cement of the well" on the Deepwater Horizon drilling rig BP leased from TransOcean (p. 97). BP had "cancelled a recommended cement bond log test" prior to the April explosion "for reasons of delay and costs" (Schultz et al., 2012, p. 97). Ultimately, despite the company agreeing to a $\$ 20$ billion fund to compensate people affected by the oil spill, BP CEO Tony Hayward was forced to step down. He was replaced by Bob Dudley on October 1, 2010. The company is currently on a mission to repair its damaged image and repair the damage to the Gulf.

\subsection{Electronics Giant Shaken by Fraud}

Satyam was founded by Ramalinga Raju in 1987 and went public in 1992. On January 8, 2009, Raju, the company's chairman and co-founder exposed his own acts of accounting fraud to the board of directors in a four-and-a-half-page letter. He confessed that Satyam's accounts had been falsified for several years. He admitted to manipulating accounts in excess of over $\$ 1.5$ billion. Subsequently, Raju resigned after admitting in his letter to shareholders that he had systematically falsified accounts as the company expanded from a handful of employees into the India's fourth largest IT company with a workforce of 53,000 and operations in 66 countries. Satyam's shares fell to the bottom of the New York Exchange due to the scandal. By March 2009, the company's shares were trading around $\$ 1.80$, compared to a high of $\$ 29.1$ in 2008 . Raju's scandal and actions had suddenly triggered what interim chief executive, Ram Mynampati called "a crisis of unimaginable proportions." Some analysts in India had dubbed the Satyam scandal as "India's Enron," one of the biggest frauds in India's corporate history. In the aftermath of Satyam fiasco, the company subsequently was taken over by the Mahindra Group and unveiled its new brand identity "Mahindra Satyam" in June 2009 in a massive attempt to rebound.

The cases for this study -BP and Satyam - were selected because of their exemplary nature. These two cases are 
analogous, each representing the types of crisis situations that have come to characterize modern-day organizations - accidents, environmental crises, corporate greed and fraud. The two cases also involve poor leadership. Both leaders engaged in misdeeds that decreased stakeholder confidence and pushed their companies further into a state of crisis.

\section{Literature Review}

\subsection{Stakeholders and Crises}

In his milestone book, Strategic Management, Freeman (1984) advocates that corporations should serve all groups or individuals who have a stake in the corporation. He notes that organizations would not exist without the support of these groups or "stakeholders" (p. 31). Further, Freeman explains that if an organization neglects a stakeholder group, that group has the ability to negatively impact the organization. Through his framework, Freeman encourages us to re-conceptualize our thinking about organizational responsibility.

Stakeholder theory, as it relates to communication in organizations, focuses primarily on those groups or individuals who are ultimately affected by or have a stake in the organization's success or failure (DeBussy, Ewing \& Pitt, 2003). Lewis (2007) states stakeholders are characterized by the extent of "power, legitimacy and urgency" they have in the organization (p. 178). These audiences are important to the life cycle of an organization and "the welfare of society" (Cornelissen, 2011, p. 40). Since their level of engagement tends to spike during occurrences like organizational crises, it is incumbent upon organizational leaders to see them not just in economic terms. It is clear in today's business environment that these groups weld much power and have great influence in holding companies accountable for their actions.

The stakeholder framework has gained much attention in both the business and communication literature in recent years in light of its applicability from the perspective of researchers and practitioners (Alpaslan, Green \& Mitroff, 2009; Ulmer, 2001). Alpaslan, Green and Mitroff (2009) point out that, in the context of crises, a stakeholder model of corporate governance may help organizations prevent crises or recover from them more successfully. Based on this perspective, the stakeholder concept provides a suitable approach for dealing with issues of CSR. In an analysis of the post-crisis communication of Malden Mills' handling of a 1995 fire that destroyed the textile mill, Ulmer (2001) demonstrates "the importance of establishing strong communication channels and positive value positions with stakeholders" in corporate governance (p. 590). He further confirms "the emphasis on ... critical communication relationships makes stakeholder theory particularly useful to crisis communication" (p. 593).

In responding to a crisis, organizations that adopt the principles of stakeholder theory are "more likely to avert crises and their costly consequences such as lawsuits and bankruptcy" (Alpaslan, Green, \& Mitroff, 2009, p. 45). In this study, stakeholder theory is thus utilized to provide a glimpse of the post-crisis actions of these two companies in resolving their crises. The major stakeholders for BP and Satyam include employees, customers, suppliers, legislators, advocacy groups, media, local government, law enforcement and in a sense, the community at large. For BP, the stakeholders in particular may also include families of those killed in the explosion.

\subsection{Communication and Corporate Social Responsibility}

Corporate social responsibility (CSR) posits that a company should be held accountable for any of its actions that affect its stakeholders, community and its environment. Elkington (1999) describes CSR as the "triple bottom line": people, planet and profits. He suggests that corporations need to communicate their CSR activities across these dimensions. More specifically, the activities include social (people), environmental (planet) initiatives and the generation of healthy financial accounts (profits). The concept of "people" refers to all labor and social issues related to internal and external stakeholders. "Planet" refers to the responsibility of organizations to include ecological care into their business operations. "Profit" deals with the traditional bottom line and a company's cash flow operations.

Seeger and Ulmer (2003) indicate "responsibility is a fundamental concept in organizational ethics" (p. 60). Organizational ethics concerns essential judgments of good and bad, right and wrong, acceptable and unacceptable, worthy and unworthy, legitimate and illegitimate behavior. When organizations are indifferent and deviate from personal responsibility there is a loss of "ethos," reputation and moral standing, which places stakeholders in the role of victim (Seeger, Sellnow \& Ulmer, 2003). A company's unethical handling of a crisis can exacerbate this phenomenon. Crises can impede an organization's ability to be proactive, often requiring organizational leaders to react quickly to the event and respond to various publics simultaneously. This becomes even more critical perhaps when the crisis event takes place outside the company's headquarters (as is the case 
with BP), or when reactions to the event are framed beyond the company's domestic reach, as was the case with both companies in this body of work.

As organizations around the world experience crises, they are finding their audience goes beyond the local individuals directly affected by these events. Today's leaders who are forced to navigate the waves of organizational crises are finding it necessary to craft messages that speak to a more global audience and provide ethical leadership that personifies the values that are intrinsic to global standards.

The success of the modern day corporation is weighted not only against its ability to maintain market share, but this success is directly tied to its ability to facilitate and negotiate relationships with the public by communicating its goals and demonstrating good corporate citizenship - which, in a sense, maintains a social order of sorts (Goss, 2002). However, organizations disturb this "social order" when they become engaged in activity that is perceived as unethical, illegal, and inconsistent with societal standards for professionalism and ethical business practices. As Kuhn and Ashcraft (2003) point out, the 21st century was marked by record numbers of corporate scandal, particularly in the U.S. "The scandals devastated more than the market values and credit ratings of companies...the incidents shook public faith... [and] contributed to a painful economic decline" (p. 21). These crises contributed to what Child and Rodrigues (2003) characterize as "an international crisis of confidence in corporations... linked with the broader wave of criticism leveled against them for their conduct in society as a whole" (p. 233).

Large corporations are in a delicate position in society because they "represent the greatest concentration of economic power" and are more likely to come under government and public scrutiny for wrong deeds - deeds which can threaten their attempts at maintaining social legitimacy (Child \& Rodrigues, 2003, p. 233). When an organization is criticized for wrongdoing, the situation can easily escalate into a crisis. This often happens when the organization is thought to be incompetent or is seen as being careless with regards to its responsibility to the community.

When Exxon's tanker Valdez ran into an Alaskan reef in 1989, spilling 1.5 million gallons of crude oil, chairman and CEO Lawrence Rawl defended the company and sought to avoid responsibility by blaming the rig's captain, Joseph Hazelwood, for the spill and the State of Alaska for the failed clean-up. At the very time when cooperation was needed, Rawl became engaged in a public dispute with Alaska's Governor Steve Cowper. The Exxon Valdez oil spill is generally recognized as a public relations disaster that was compounded by Rawl's behavior (Small, 1991). Exxon may have experienced a more successful crisis response had it put more energy into its substandard plans and preparation activities (Pearson \& Clair, 1998).

The Exxon example is in stark contrast to the bond trading firm of Cantor Fitzgerald's management following the World Trade Center disaster. It was the company hardest hit by the September 11, 2001 attacks. Cantor Fitzgerald lost over 658 of its employees, including CEO Howard Lutnick's brother, Gary Lutnick. In the aftermath of the crisis, Howard Lutnick not only vowed to rebuild the firm but also "focused on helping his primary stakeholders - the families of those who lost members in the tragedy" (Ulmer, Sellnow \& Seeger, 2007, p. 179). In a television interview with $A B C$ 's Connie Chung on September 13, 2001, Lutnick said, "there is only one reason to be in business - it is because we have to make our company be able to take care of our 700 families. Help them... I can't say it without crying. That's my American dream now" (Russakoff \& Cha, 2001).

His emotional response to the crisis gave stakeholders a vision for the company's future. On September 19, 2001, Lutnick committed to distribute 25 percent of the firm's profits over five years to pay for ten years of health insurance for the families of its 658 dead employees (Pressler, 2011). In the past ten years, the company has completed its promise. Cantor Fitzgerald was ultimately able to draw on a reservoir of goodwill, help the company survive and rebuild its organization (Ulmer, Sellnow \& Seeger, 2007).

\subsection{Transparency and Accountability}

Today, legal restrictions force organization to disclose information about their actions and present themselves in legitimate ways. In particular, business analysts and media increasingly scrutinize business practices. Hooghiemstra (2000) elaborates that "social and environmental disclosures are responses to both public pressure and increased media attention resulting from major social incidents" such as an oil spill or chemical leak (p. 55). The literature clearly points out that organizations must be more open and transparent with their communication. Transparency is defined as "the degree to which information is available to outsiders that enables them to have informed voice in decisions and/or to assess the decisions made by insiders" (Florini, 2007, p. 5). Fombrun and Rindova (2000) argue that transparency is "a state in which the internal identity of the firm reflects positively the expectations of key stakeholders and the beliefs of these stakeholders about the firm reflect accurately the internally held identity" (p. 94). 
Balkin (1999) identifies three types of transparency: informational, participatory, and accountability which "often work together but are analytically distinct" (p. 393). The informational element represents information that is truthful. The second element includes participation of stakeholders in identifying the information they need. The final element, accountability emphasizes objective, balanced reporting of an organization's activities that holds the organization accountable (Rawlins, 2009). In line with this notion, transparency also implies openness, communication, and accountability. Similarly, Coombs (2007) suggests that the openness of an organization means: 1) availability to the media, 2) willingness to disclose information, and 3) honesty (p. 132). In this way, stakeholders are not only able to have access to corporate information but also expect that the companies are held accountable for their performance.

From the company's perspective, organizational information is private and not subject to public disclosure. As such, companies have a significant interest in keeping its information confidential, particularly to protect financial data. The corporate financial scandals involving Enron, Tyco and WorldCom illustrate the severe negative effects on stakeholders who rely on false representations about a company's financial status. Transparency is thus a necessary condition for financial success at the firm level (Bowie, 2004). Cotterrell (2000) states that "transparency as a process involves not just availability of information but active participation in acquiring, distributing and creating knowledge" (p. 419). The reason is simple: less information means less certainty for stakeholders. Belasen (2008) further points out that the lack of transparency creates asymmetry between communication activities and stockholders' knowledge about outcomes such as cash flows.

Rawlins (2009) argues "transparency has been tied to trust, corporate social responsibility, and ethics" (p. 72). This kind of trust is reciprocal and should be demonstrated by the organization that opens itself up to its stakeholders (Koehn, 1996). Therefore, it is thought that exposing wrongdoing is needed to correct corrupt practices (Stoker \& Rawlins, 2005). For example, the collapse of the HIH (CE Heath International Holdings) Insurance clearly "delineates the importance of transparency and open communication" (Cheng \& Seeger, 2012, p. 83). HIH's collapse on March 15, 2001, signaled the largest corporate failure in Australian business history. The executives of HIH downplayed warning signs of financial crisis. They had been reluctant to disclose the state of HIH's deteriorating position. Cheng and Seeger (2012) note, "lies and deception within HIH hurt corporate profitability, accountability and image" (p. 74). All the usual mechanisms for preventing corporate collapse failed at $\mathrm{HIH}$.

On a practical level, stakeholder theory can lead to outcomes that dictate for a company the kinds of initiatives they should engage. Recent communication studies have focused on the role of ethical leadership in CSR efforts. Research has also confirmed that a company's support during times of crisis is influenced by the continuum of goodwill that can only come from a reputation of ethical behavior (Coombs, 2004). Furthermore, transparency and accountability can be regarded as a necessary mechanism for promoting CSR.

\section{Method}

As a foundation for this analysis, we used daily newspapers within and outside of the U.S.; trade industry publications related to the two industries these companies represent; news magazines, which provided more detailed coverage of the crises and chronologies of the events; broadcast transcripts from interviews with company officials; news releases from company web sites; transcripts of speeches delivered by company officials; and other company-generated documents such as annual reports. In addition to news reports and company-generated news releases, we used more measurable forms of data, including public opinion polls and stock values.

Texts collected for BPs oil spill represent a timeline from April to November, 2010, when the investigation into the spill concluded. Texts collected for Satyam represented a five-month period, starting on December 30, 2008, when Satyam's stock price plunged enormously due to Raju's attempt to acquire Maytas, and ending on April 13, 2009 , when the company unveiled its new brand identity. As much of the research on crisis cases focuses on only one case, this project draws from two cases and supports Yin's (2009) assertion that " evidence from multiple cases is often considered more compelling" (p. 53).

To each case we apply a thick description rhetorical analysis that provides a close read of various texts. This is followed up with a thematic analysis to identify recurring themes found within the case (Braun \& Clarke, 2006). Thematic analysis is a flexible method for "identifying, describing, analyzing and reporting themes and patterns within data" (Braun \& Clarke, 2006, p. 79). We generated themes between the two cases and focused the analysis on the themes that emerged the most in the artifacts collected. These themes help us to explore communication tools used by crisis responders to keep the public informed and engaged as each crisis unfolded. The three themes that were most salient in the rhetorical responses of BP and Satyam following each company's 
crisis were: 1) issues of blame and accountability, 2) issues of transparency, and 3) success or failure of the crisis response.

The first theme, blame and accountability include blame levied against the organization and/or the organization's leaders; the degree to which organizational leaders assume responsibility for their crises and whether they shift blame to others. From the artifacts, 12 of the 17 items used in the BP case and 7 of the 11 items in Satyam's crisis highlighted issues of blame and accountability. Among the major topics in the BP oil spill case was President Obama putting pressure on BP CEO Tony Hayward and Hayward shifting blame to subcontractors. Satyam's finger-pointing between its Charman Raju and CFO Vadlamani was the subject of many of its news reports.

The second theme, transparency, refers to the candor of organizational leaders and their willingness to engage issues surrounding the crises. Transparency explores the degree to which organizational leaders concealed or made available information/documents, their availability for news conferences and other methods for keeping the public informed, and the platforms or mechanisms used to keep the public informed. Four of the 17 items in BP's case and nine of the 11 items in Satyam's case dealt with the issue of transparency. Among the major topics were Hayward's use of "town hall-type meetings," the establishment of a 24-hour call center, and use of multiple social media platforms to maximize interactive communication. A main topic among the coverage of Satyam's case was commentary about company leaders downplaying the financial crisis and "cooking" the books over a seven-year period. Issues of transparency related to the BP case included more calls for the company to provide consistent communication about efforts to cap the thousands of gallons of oil gushing into the Gulf each day in the early stages of the crisis.

The final theme, success or failure of crisis response involves identifying strategies used by organizational leaders to manage crises and perceptions about the effectiveness of the strategies. We base this on a close read of the news coverage and other indicators of public opinion, including polls. Thirteen of the 17 items in BP's case and four of the 11 items in Satyam's case dealt with success or failure of crisis response. Among the major topic in BP's case was Hayward's insensitive comments in the wake of the crisis and perceptions that he mishandled the response effort to cap the spill, which took over three months. In Satyam's case, the focus was more on government intervention as a sign that efforts to recover from the fraud were failing.

\section{Analysis}

\subsection{Case Study One: BP (Formerly British Petroleum)}

\subsubsection{BP - Issue of Blame and Accountability}

BP faced increased pressure from the Obama administration not only to cap the spill, but also to address the environmental concerns and to bring corrective action related to the mounting claims (Knickerbocker, 2010). While there was much criticism in the U.S., views of Hayward were more favorable in the U.K., where he "was greeted by a standing ovation as he held the first in a serious of town halls at the company's headquarters (Langley, 2010).

In the U.S., Hayward fought an uphill battle to gain support. In a $C N N$ opinion poll on May 24, 2010, 76 percent of respondents disapproved of the way BP handled the oil spill (CNN opinion research poll, 2010). Fifty-one percent disapproved of the way President Obama handled the spill. Of those polled, 53 percent predicted that efforts to control the spill and prevent it from spreading would be unsuccessful (CNN opinion research poll, 2010).

Because of the massive extent of environmental damage and the federal government's role in the cleanup effort, President Obama shared the role of crisis leader with Hayward. Giving the American people assurance, President Obama clarified in a news conference on May 27, 2010:

From the moment this disaster began, the federal government has been in charge of the response effort. As far as I'm concerned, BP is responsible for this horrific disaster, and we will hold them fully accountable on behalf of the United States as well as the people and communities victimized by this tragedy... But make no mistake: BP is operating at our direction. Every key decision and action they take must be approved by us in advance. (The White House, 2010)

In addition to the President, government officials fanned the flames of the fire raging around BP. In an article in The Times, Pagnamenta (2010) cites two government officials' reactions to the crisis. The first, White House Advisor Carol Browner, characterized the oil spill as "probably the biggest environmental disaster we have ever faced in this country." Her colleague said, "I think without question if the word criminal should be used in terms of an environmental crime against our country, then what's going on in the Gulf of Mexico is going to qualify" 
(Pagnamenta, 2010).

BP's road to accountability was rocky at best. In the first few days after the explosion, Hayward repeatedly told reporters that "it wasn't our accident" (Bergin, 2010). Instead, he blamed Transocean, the offshore drilling rig contractor. Additionally, BP initially "refused to compensate fisherman who were unable to produce written proof of their normal earnings, when most did not keep those kind of records" (Webb, 2010). BP also required fisherman signing up to help with the cleanup to "sign agreements limiting their receipt of future damages from BP" (Webb, 2010).

\subsubsection{BP - Issue of Transparency}

This was an area where BP gained momentum after the firestorm of criticism over its initial response. In the intermediate stage of the crisis, Hayward was called before U.S. Congress. In his statement in front of a U.S. congressional committee on the spill, Hayward assured the public that BP was "working hard to keep the public and government officials around the country informed" (BP CEO's testimony, 2010). The company held town hall meetings with employees in the U.S. and the U.K. Hayward also mentioned and President Obama confirmed in a separate statement that BP was working closely with the federal government to coordinate the cleanup effort (Oil spill answers, 2010).

To manage the influx of over 50,000 claims that had been submitted by July 2010, Hayward appointed an independent mediator to make sure the "process was fair and transparent" (BP CEO's testimony, 2010). The company established a 24-hour, seven-day-a-week call center and created claim centers in the four affected states-Alabama, Florida, Louisiana, and Mississippi. BP also posted daily briefings on its web site documenting its progress and set up an entire site dedicated to the cleanup effort. Within 30 days after the explosion BP announced the creation of "four informational web sites designed to offer state-specific oil spill information to residents of [affected] communities" (BP press releases, 2010a) The creation of these sites was a deliberate attempt to provide information, but BP also used them to maximize interactive communication with this audience by providing an RSS and Twitter feed and a link to a Facebook page. Residents could also sign up to receive email updates. BP made it clear on its web site that "these community-focused web sites are part of [the company's] effort to engage with the communities of affected areas" (BP press releases, 2010a).

Once the spill was capped in July 2010, public criticism of the company began to quiet. BP kept momentum going by making significant attempts to provide stakeholders with current and continuous information related to the processing of claims and the clean-up effort. BP focused corrective action efforts on local communities. Early restoration projects were designed to help the Gulf's economic and environmental recovery. Although legitimate efforts have been made to bring equilibrium to the region, BP is not out of danger. The future of the eco-system in the Gulf region is far from secure.

\subsubsection{BP - Success or Failure of Crisis Response}

Like Exxon in 1989, the company initially underestimated the severity of the damage and the length of time necessary to bring recovery to the battered region (Williams \& Treadaway, 1992). Hayward's initial assessment of the crisis did not ring well with his U.S. target audience. He stated, "The relief wells will ultimately be successful. The company will solve the problem. It's simply a question of how long it takes" (Gonzalez, 2010). The sentiment building up after the crisis was "everyday crude oil was still leaking into the ocean, U.S. anger toward BP mounted" (Tony Hayward says BP was not prepared, 2010). In fact, The New York Daily News thus called him "the most hated and clueless man in America" (Kennedy, 2010).

BP's response got off to a rocky start because of early faux pas by its leader, Tony Hayward. In particular, he had not represented the company well in media interviews and portrayed himself as the victim. His comment, "there's no one who wants this thing over more than I do, I'd like my life back" did not fare well in the backdrop of the lives lost during the explosion (Durando, 2010). Later in an interview, he seemed to paint a picture of himself as a scapegoat, saying he was painted as a villain [by U.S. media] (Langley, 2010). This strategy, articulated by Benoit (1995) is called attacking the accuser. Hayward used this strategy to attack the U.S. media, who had begun to lose patience with BP's efforts to cap the spill.

Despite BP's efforts to get in front of the crisis, the company seemed to struggle to keep up with the wave of public criticism. In an $A B C$ news poll on July 14, 2010, 79 percent of residents in the Gulf counties called the spill a major disaster and 61 percent favored criminal charges against BP and other companies involved (Langer, 2010). While many mistakes were made, the strength of BP's response was clearly from the words of culpability that Hayward spoke after it became clear that capping the spill was no small undertaking.

After he initially shifted the blame, Hayward followed up with mortification, which was appropriate considering 
this crisis involved an explosion that resulted in death and injuries and the severity of the oil spill caused an environmental disaster that will take years, if not decades, to resolve. Mortification is often used when other strategies have failed (Benoit, 1995). While news reports generally focused on the company's failure to meet the demands of the enormity of this crisis, it remains to be seen how the company will be viewed historically in the wake of this massive response effort. Subsequent to the explosion, Hayward was asked to step down as group chief executive on October 1, 2010 and was succeeded by Bob Dudley.

Despite the fact that the damage caused by the accident in the Gulf was severe and Hayward's response was ineffective, some experts and critics note that BP was "reasonably well prepared" in terms its corrective action measures (Helman, 2010). Within 24 hours, the company muscled together "32 response vessels, 1 million feet of containment boom and six firefighting ships" (Helman, 2010). The massive response effort was coordinated by $\mathrm{BP}$, monitored by the federal government, and included " 470 engineers and managers from 70 companies... as well as government agencies, working 12-hour shifts around the clock" (Helman, 2010). In a company-issues press release, Steve Benz, President and CEO of the Marine Spill Response Corporation (MSRC) said, "at BP's request, we are mounting the single, largest response effort in MSRC's 20 year history" (BP press releases, 2010b).

\subsection{Case Study Two: Satyam}

\subsubsection{Satyam - Issue of Blame and Accountability}

Thadhani, a Gilford Securities analyst argues that the Satyam story is a textbook example of greed and calls attention to the "dark side of Indian capitalism" (Bonasia, 2009, p. 1). The financial scam affected the image of corporate India and ethical business practices were questioned especially at a time when Indian companies were recognized as a commercial superpower and a major force in global outsourcing and data management (Nocera, 2009). Satyam's Chairman, Raju lied and cheated shareholders and doctored financial reports, reporting $\$ 555$ million of sales when actual sales were $\$ 434$ million. Profit reported was $\$ 136$ million when the actual profit was only $\$ 12.5$ million. The available cash that Raju disclosed was $\$ 1$ billion, but in reality, the company only had $\$ 66$ million (Sheth, Range \& Anand, 2009). Satyam's board was dissolved over the crisis and CFO Vadlamani Srinivas resigned. Partners from Price Waterhouse Coopers ( $\mathrm{PwC}$ ), the firm that audited Satyam's accounts, were taken into custody by the Central Bureau of Investigation (CBI), India's criminal intelligence investigation agency.

In his letter of resignation, Raju described how an initial cover-up for the poor financial performance escalated:

What started as a marginal gap between actual operating profit and the one reflected in the book of accounts continued to grow over the years... The differential in the real profits and the one reflected in the books was further accentuated by the fact that the company had to carry additional resources and assets to justify higher level of operations-thereby significantly increasing the costs... Every attempt made to eliminate the gap failed. (Raju's resignation letter to the board, 2009)

This debacle clearly created an ethical dilemma for Satyam. Raju further described the dilemma synonymous to "riding a tiger, not knowing how to get off without being eaten." He took corrective actions and apologized to all stakeholders and reminded stakeholders of Satyam's solid industry work.

I sincerely apologize to all Satyamities and stakeholders who have made Satyam a special organization, for the current situation. I am confident they will stand by the company in this hour of crisis. (Raju's resignation letter to the board, 2009)

As the bad news spread, the finger-pointing between chairman Raju and CFO Vadlamani began unabated. Raju said he had "manipulated the balance sheet to attract more business" for seven years and instructed the company's chief financial officer to do so (Ramalinga Raju confesses, 2009). However, in Vadlamani's confessional statement, he denied having anything to do with handling bank balances. Vadlamani added that "bank deposits were directly handled by the chairman and managing director. I was specifically asked not to look into that area of operation" (Ramalinga Raju confesses, 2009).

Just three months before Raju's fraudulent assertions, Satyam won a Golden Peacock award from the World Council for excellence in corporate governance, which was stripped from them in the aftermath of the scandal. Although Minister for Corporate Affairs, Prem Chand Gupta called the Satyam case an aberration, the damage had already sullied India's corporate image. 


\subsubsection{Satyam - Issue of Transparency}

According to standard financial accounting practices, publicly traded companies must provide updated financial information to the public. Stockholders have the right to know about the activities that potentially may have an impact on their investments. Unfortunately, Raju downplayed the deteriorating financial situation. On December 16, 2008, Satyam attempted to acquire two struggling companies (Maytas Infrastructure and Maytas Properties) at an inflated price without proper shareholder approval. Both companies were owned and controlled by Raju's family members. This eventually led to harsh criticism by stakeholders. Lack of corporate governance was blamed for not taking concerns of investors into consideration. The investors claimed that it was an irresponsible misuse of funds and an act of nepotism. In his resignation letter, Raju admitted his fraud following an aborted attempt to acquire Maytas firms:

The aborted Maytas acquisition deal was the last attempt to fill the fictitious assets with real ones. Maytas' investors were convinced that this is a good divestment opportunity and a strategic fit. Once Satyam's problem was solved, it was hoped that Maytas payments can be delayed. But that was not to be. (Raju's resignation letter to the Board, 2009)

On December 23, 2008, the World Bank barred Satyam from bidding on its projects because the company was providing improper benefits to bank staff in exchange for contracts. To complicate things further, on December 26, 2008, Merrill Lynch signed on as an advisor to Satyam, doing its due diligence. But within 10 days the company quit the project, engaging material accounting irregularities was the reason for the decision (DSP Merrill Lynch terminates engagement with Satyam, 2009). Satyam's accounts had been audited by PwC since the financial year 2001. Arguably, in years PwC could not detect a problem, yet Merrill Lynch sensed the deceit in days.

On December 31, 2008, Raju sent out an internal letter to employees regarding his interest in diversifying Satyam in an attempt to regain confidence, especially when the share price dropped to about 80 percent. In the letter he said:

We have also been in contact with many of our investors, and we have taken key steps to regain their confidence. These include strengthening the board by changing its size and composition, and engaging DSP Merrill Lynch to provide strategic advice and options. The board will meet on January 10, 2009 to consider these options and to chart a course of action that would boost stakeholders' confidence further. Please be assured that the board and the leadership team are doing everything possible to get Satyam back on track. (Satyam crisis update, 2008)

The letter was further evidence of Raju's unethical leadership, hiding the truth from the stakeholders that the company was in a financial crisis. He did make general references to fixing Satyam's issues, but was never clear about the extent of the damage he had caused. Belasen (2008) suggests that "financial results should be communicated in a consistent, conclusive, and concise way and in a manner that shows the company is proactive and responsive" (p. 77). Raju's lack of communication increased the impression that the company was hiding something.

The interim CEO Myampati, conducted a press conference and issued statements to the press explaining the preventive measures adopted by Satyam in aftermath of financial crisis. Although company officials did update employees on the developments of the crisis, it installed a firewall to block them from sending any comments pertaining to the crisis on the Internet. This was somewhat effective in controlling the flow of external communication following the crisis.

Much of the company's emphasis was on internal communication. In the aftermath of the crisis it was the internal communications that helped to garner employee support. Departments at Satyam came together and rallied together on a road to recovery. Although Satyam did lose some accounts during the crisis, a press report showed Satyam signed fifteen new contracts despite the troubles (Flinder, 2009).

\subsubsection{Satyam - Success or Failure in Crisis Response}

Government intervention played a major role in helping Satyam recover from crisis. After Raju's revelation, the government made significant changes to the company's Board of Directors. The government nominated a ten-member committee to oversee the operations of the organization. In a statement from a government official, Minister Gupta, he said, "it is the prime concern of the government to ensure that the operations of the company continue uninterrupted" (Gupta, 2009). He asserted further, "the credibility of the IT industry should not be allowed to suffer."

After the scandal broke, the board of directors was dismissed and the company's chairman Ramalinga Raju and 
his brother B. Rama Raju were jailed. An interim CEO Ram Myampati was appointed. On January 8, 2009, Mynampati announced at a conference that several immediate actions already were being undertaken by the leadership team. The actions included formulating a task force to address all ongoing operational issues to ensure business continuity and began a process to ascertain Satyam's financial liquidity position. Moreover, Mynampati boosted morale and emphasized that the company placed top priority on protecting the careers and livelihood of employees and their families. In a company news release, he said "We share the pain and grief being felt by all associates and their families and will do our utmost to ensure that salaries can be paid. We are extremely touched by the outpouring of support from associates" (Satyam News Releases, 2009).

Two days after the crisis, Interim CEO, Myampati, left for the United States to assure its international customers that the situation at Satyam was under control and the company was doing everything it needed to maintain its customer base. Satyam's executives went door-to-door to meet their customers in New York. Satyam's leadership sent emails daily to assure its 53,000 employees it would rebound and that its international clients were sensitive to the company's global position. In some cases they conducted town-hall meetings to reassure Satyam staff that its contracts were safe (Bellman \& Sheth, 2009). The crisis did create a stain on the organization, but the effective steps toward corrective action taken by the government helped to salvage Satyam's and preserve the country's image.

\section{Discussion}

Research has demonstrated that organizational leaders who demonstrate ethical conduct and maintain open communication are better equipped to help their organizations move beyond crises (Seeger \& Ulmer, 2001). Although its CEO was not seen as an effective leader in the crisis because of insensitive statements he made early in the BP's crisis, the establishment of a web site solely devoted to the recovery effort created opportunities to be more transparent about specific actions the company was taking. Even though BP's disaster was not directly the fault of its CEO, Hayward assumed part of the blame and took full responsibility for the clean-up effort. However, his eventual apology for the explosion "failed to resonate with the public" (Muralidharan, Dillistone \& Shin, 2011, p. 227). This is due to the fact that apologies are seen as more meaningful when they are made up front, not as a last resort. Perhaps if Hayward had not started with attempts toward shifting the blame and subsequent attempts to attack his accusers by lashing out again U.S. media, his apology may have been perceived as more sincere.

As it relates to transparency, BP did establish a clear communication through press releases and consistent use of the Internet to communicate with key publics associated with the crisis. It remains to be seen the long-term impact of these actions to BP's image, but the strategy has helped to manage the volume of complaints that have poured into the organization since the oil spill. In an attempt to create "an image of transparency," corrective action was the dominant strategy employed by BP in social media (e.g., Facebook, Twitter, YouTube, and Flickr) (Muralidharan, Dillistone \& Shin, 2011, p. 231).

Although their study only focused on the initial stage of BP's crisis, W. Harlow, Brantley and R. Harlow (2011) found through content analysis that BP made significant use of the attacking the accuser strategy, along with mortification and corrective action measures. The company seemed to recognize that its limited use of blame-shifting were ineffective and shifted its focus toward compensating victims and use of corrective action. The true test of BPs success will be the conclusion of its recovery effort.

This study attempts to contribute to the growing body of research on corporate crises by explicating how issues of blame, transparency and accountability can either be detrimental to a company's post-crisis repair or enhance it. One of the limitations of this study was BP's analysis was constrained to the period from the initial explosion leading up to BPs report from the investigation. Future research should revisit this crisis at a later period in the crisis cycle to examine the extensive recovery effort in the Gulf that is still in progress today.

In the case of Satyam, organizational leaders were directly responsible for the unethical actions associated with the crises. It is clear that "corporate executives were not aware of or ignored their potential unethical practices and eventually created a crisis for their organization" (Cheng \& Seeger, 2012, p. 83). Satyam's CEO had dishonored his company and country by his actions and was deemed unworthy to lead. The fact that he resigned under the guise of "in the interest of" the company points to efforts by company officials to distance themselves from the crisis in order to improve corporate image. The government quickly intervened and took immediate steps to preserve the company's reputation and negotiate its financial status. However, Satyam's debacle continued to tarnish India's business practices and raise questions about their corporate governance system.

Although there was government intervention in both cases, India's government functioned primarily to help Satyam save face in the financial community and to establish ethical mandated to prevent future occurrences. 
The U.S. government functioned more to pose sanctions on BP and guide the course of the recovery effort. Some have also argued that President Obama's involvement was a strategic move for the White House to save face, not so much in the financial community, but socially.

The need for effective post-crisis communication was a common theme among these cases. The use of corrective action was something both companies had in common. Each company employed corrective action to demonstrate accountability among key stakeholders in an effort to rebuild their tarnished images. There was evidence in their post-crisis communication of greater levels of transparency, but only after threats to market share and global reputation. This further cements the notion that it is difficult for corporations to balance the responsibility between their commitment to shareholders to stay in business and their commitment to the community and broader environment to demonstrate good citizenship. We may never see a time when the latter is of greater priority than the former, but a company's stakeholders can greatly influence its survival.

Studies like this are important to the discussion of ethical and responsible behavior among multinational organizations. If the company has a history of acting in a socially responsible way, they not only have a better chance of recovery from crisis, they will likely suffer less reputational damage during and after the incident. This case reminds us that crises can create uncertain environments. In times of uncertainty, it becomes incumbent upon organizational executives to display a kind of "virtue ethics" that helps stakeholder to perceive them as not only responsible, but responsive to their expectations.

\section{References}

Alpaslan, C. M., Green, S. E., \& Mitroff, I. I. (2009). Corporate governance in the context of crises: Towards a stakeholder theory of crisis management. Journal of Contingencies and Crisis Management, 17(1), 38-49. http://dx.doi.org/10.1111/j.1468-5973.2009.00555.x

Balkin, J. M. (1999). How mass media simulate political transparency. Cultural Values, 3(4), 393-413. http://dx.doi.org/10.1080/14797589909367175

Belasen, A. T. (2008). The theory and practice of corporate communication. Thousand Oaks, CA: Sage Publications.

Bellman, E., \& Sheth, N. (2009, January 23). Indian prosecutors allege Satyam founder. The Wall Street Journal, B1.

Benoit, W. L. (1995). Accounts, excuses, and apologies. Albany, NY: State University of New York Press.

Bergin, T. (2010, June 29). Analysis: BP PR blunders carry high political cost. Reuters. Retrieved February 3 , 2012, from http://www.reuters.com/article/2010/06/29/us-oil-spill-bp-pr-idUSTRE65S3JL20100629

Bonasia, J. (2009, February 18). Fallout from Satyam case could linger. Investor Business Daily. Retrieved January 5, 2012, from Lexis Nexis Academic.

Bowie, N. E. (2004). Why conflicts of interest and abuse of information asymmetry are keys to lack of integrity and what should be done about it. In G. G. Brenkert (Ed.), Corporate integrity \& accountability (pp. 59-71). Thousand Oaks, CA: Sage Publications. http://dx.doi.org/10.4135/9781452225685.n6

BP CEO's testimony draws unbraiding by many on House energy panel. (2010, July 17). PBS Newshour. Retrieved March 14, 2011, from http://www.pbs.org/newshour/bb/environment/jan-june10/oil_06-17.html

BP press releases. (2010a, May 25). BP announces launch of state-specific response web sites: Sites offer information and updates with information of interest to local communities. Retrieved January 5, 2012, from http://www.bp.com/genericarticle.do? categoryId=2012968\& contentId=7062443

BP press releases. (2010b, April 25). BP forges ahead with Gulf of Mexico oil spill response. Retrieved January 5, 2012, from http://www.bp.com/genericarticle.do? categoryId=2012968\& contentId=7061518

Braun, V., \& Clarke, V. (2006). Using thematic analysis in psychology. Qualitative Research in Psychology, 3(2), 77-101. http://dx.doi.org/10.1191/1478088706qp063oa

Cheng, S., \& Seeger, M. (2012). Lessons learned from organizational crisis: Business ethics and corporate communication. International Journal of Business and Management, 7(12), 74-86. http://dx.doi.org/10.5539/ijbm.v7n12p74

Child, J., \& Rodrigues, S. (2003). The international crisis of confidence in corporations. Journal of Management and Governance, 7, 233-240. http://dx.doi.org/10.1023/A:1025062422500 
CNN opinion research poll. (2010, May 24). CNN. Retrieved February 11, 2012, from http://i2.cdn.turner.com/cnn/2010/images/05/24/rel8a.pdf

Coombs, W. T. (2004). Impact of past crises on current crisis communications: Insights from situational crisis communication theory. Journal of Business Communication, 41, 265-289. http://dx.doi.org/10.1177/0021943604265607

Coombs, W. T. (2007). Ongoing crisis communication: Planning, managing, and responding (2nd ed.). Thousand Oaks, CA: Sage Publications.

Cornelissen, J. (2011). Corporate communication: A guide to theory and practice. Thousand Oaks, CA: Sage.

Cotterrell, R. (2000). Transparency, mass media, ideology and community. Cultural Values, 3, 414-426. http://dx.doi.org/10.1080/14797589909367176

DeBussy, N. M., Ewing, M. T., \& Pitt, L. F. (2003). Stakeholder theory and internal marketing communications: a framework for analyzing the influence of new media. Journal of Marketing Communication, 9, 147-161. http://dx.doi.org/10.1080/1352726032000129890

DSP Merrill Lynch terminates engagement with Satyam. (2009, January 6). The Gaea Times. Retrieved January 21, 2012, from http://tech.gaeatimes.com/index.php/archive/dsp-merrill-lynch-terminates-engagement-with-satyam/

Durando, J. (2010, June 1). BP's Tony Hayward: I'd like my life back. USA Today. Retrieved February 2, 2012, from http://content.usatoday.com/communities/greenhouse/post/2010/06/bp-tony-hayward-apology/1

Elder, L. (2005). Group wants powerful acid out of BPs plant. Retrieved February 5, 2013, from http://newspaperarchive.com/galveston-daily-news/2005-03-27

Elkington, J. (1999). Cannibals with forks: the triple bottom line of 21 st century business. Oxford: Capstone.

Flinder, K. (2009, January, 8). Satyam emergency conference reveals recovery plans. Retrieved January 5, 2012, from http://www.computerweekly.com/news/2240087984/Satyam-emergency-conference-reveals-recovery-plans

Florini, A. (2007). The battle over transparency. In A. Florini (Ed.), The right to know: Transparency for an open world (pp. 1-18). New York: NY: Columbia University Press.

Fombrun, C. J., \& Rindova, V. P. (2000). The road to transparency: Reputation management at Royal Dutch/Shell. In M. Schultz, M. J. Hatch, \& M. H. Larsen (Eds.), The expressive organization (pp. 77-96). Oxford University Press.

Fortunato, J. A. (2008). Restoring a reputation: The Duke University lacrosse scandal. Public Relations Review, 34, 116-123. http://dx.doi.org/10.1016/j.pubrev.2008.03.006

Freeman, R. E. (1984). Strategic Management. Boston, MA: Pitman.

Gonzalez, A. (2010, May 11). BP takes new tack to capture escaping oil in Gulf. The Washington Post. Retrieved January 31, 2012, from http://online.wsj.com/article/SB10001424052748703880304575235821104449994.html

Goss, D. R. (2002). A critical exploration of the rhetoric of apologia as applied to the discourse of corporate social responsibility. Unpublished dissertation. Howard University, Washington, D.C.

Gupta, P. C. (2009, January 9). Full text of statement of Prem Chand Gupta.The Times of India. Retrieved January $\quad 17, \quad 2012, \quad$ from http://articles.timesofindia.indiatimes.com/2009-0109/india-business/28009377_1_saty am-case-nominee-directors-satyam-computer-services

Harlow, W. F., Brantley, B. C., \& Harlow, R. M. (2011). BP initial image repair strategies after the Deepwater Horizon spill. Public Relations Review, 37, 80-83. http://dx.doi.org/10.1016/j.pubrev.2010.11.005

Hearit, K. M., \& Brown, J. (2004). Merrill Lynch: Corporate apologia and business fraud. Public Relations Review, 30, 459-466. http://dx.doi.org/10.1016/j.pubrev.2004.08.008

Helman, C. (2010, May 20). After the spill: Big oil plots its comeback. Forbes. Retrieved January 26, 2012, from http://www.forbes.com/forbes/2010/0607/outfront-bp-oil-petro-tony-hayward-slick-performance.html

Hooghiemstra, R. (2000). Corporate communication and impression management - new perspective why companies engage in corporate social reporting. Journal of Business Ethics, 27, 55-68. http://dx.doi.org/10.1023/A:1006400707757 
Kennedy, H. (2010, June 3). BP's CEO Tony Hayward: The most hated and most clueless man in America. New York Daily News. Retrieved February 2, 2012, from http://articles.nydailynews.com/2010-06-03/news/27065997_1_bp-brand-lord-john-browne-british-oil

Knickerbocker, B. (2010, May 22). Obama moves to take political control of BP Gulf oil spill. The Christian Science Monitor, (electronic version). Retrieved January 25, 2011, from Lexis Nexis Academic Universe.

Koehn, D. (1996). Should we trust in trust? American Business Law Journal, 34, 183-203. http://dx.doi.org/10.1111/j.1744-1714.1996.tb00695.x

Kuhn, T., \& Ashcraft, K. (2003) Corporate scandal and the theory of the firm, formulating the contributions of organizational communication studies. Management Communication Quarterly, 17(1), 20-57. http://dx.doi.org/10.1177/0893318903253421

Langer, G. (2010, July 14). Poll: Gulf Coast resident oppose drilling moratorium. ABC World News. Retrieved July 27, 2012, from http://abcnews.go.com/US/abc-news-poll-bp-oil-spill-impact-gulf/story?id=11163367

Langley, M. (2010, July 30). Hayward defends tenure, BP's spill response. The Wall Street Journal. Retrieved January $8, \quad 2011$, from http://online.wsj.com/article/SB10001424052748703578104575397483256188088.html

Lewis, L. K. (2007). An organizational stakeholder model of change implementation communication. Communication Theory, 17(2), 176-204. http://dx.doi.org/10.1111/j.1468-2885.2007.00291.x

Maresh, M., \& Williams, D. (2012). Oil industry crisis communication. In W. T. Coombs, \& S. J. Holladay (Eds.), The Handbook of Crisis Communication (pp. 285-300). Malden, MA : Wiley-Blackwell.

Muralidharan, S., Dillistone, K., \& Shin, J. (2011). The Gulf Coast oil spill: Extending the theory of image restoration discourse to the realm of social media and beyond petroleum. Public Relations Review, 37, 226-232. http://dx.doi.org/10.1016/j.pubrev.2011.04.006

Nocera, J. (2009, January 9). In India, crisis pairs with fraud. The New York Times. Retrieved March 14, 2011, from http://www.nytimes.com/2009/01/10/business/10nocera.html

Oil spill answers, Mr. Obama takes responsibility for the response - and points to the need for energy changes. The Washington Post. Retrieved January 25, 2011, from Lexis Nexis Academic.

Oles, D. (2010). Deny, delay, apologize: The Oprah Winfrey image-defense playbook. The Northwest Journal of Communication, 39(1), 37-63.

Pagnamenta, R. (2010, June 1).Oil fury wipes \$11bn from BP's value. The Times. Retrieved January 25, 2012, from Lexis Nexis Academic.

Pearson, C. M., \& Clair, J. A. (1998). Reframing crisis management. The Academy of Management Review, 23(1), 59-77. http://www.jstor.org/stable/259099

Pressler, J. (2011, August 27). Cantor Fitzgerald: The firm that lost the most. New York. Retrieved July 25, 2012, from http://nymag.com/news/9-11/10th-anniversary/cantor-fitzgerald/

Ramalinga Raju confesses he was cooking books for 7 years. (2009, January 13). The Economic Times. Retrieved January 31, 2012, from http://articles.economictimes.indiatimes.com/2009-01-13/news/27657332_1_audit-section-and-managemen t-ramalinga-raju-vadlamani-srinivas

Raju's resignation letter to the board. (2009, January 7). The Times of India. Retrieved January 17, 2012, from http://timesofindia.indiatimes.com/business/india-business/Full-text-of-Rajus-resignation-letter-to-the-Boar d/articleshow/3946538.cms

Rawlins, B. L. (2009). Give the emperor a mirror: Toward developing a stakeholder measurement of organizational transparency. Journal of Public Relations Research, 21(1), 71-99. http://dx.doi.org/10.1080/10627260802153421

Reber, B. H., \& Gower, K. K. (2006). Avow or avoid? The public communication strategies of Enron and $\begin{array}{llll}\text { WorldCom. Journal of Promotion } & \text { Management, }\end{array}$ http://dx.doi.org/10.1300/J057v12n03_12

Russakoff, D., \& Cha, A. E. (2001, September 14). Sketches of the missing: Hard-working early risers. The Washington Post, p. 24.

Satyam crisis update: Satyam chairman Raju's letter to employees. (2008, December 31). Current It Market. 
Retrieved March 14, 2011, from http://www.currentitmarket.net/2008/12/satyam-crisisupdate-satyam-chairman.html

Satyam News Releases. (2009, January 11). Satyam's top leaders announce action plan focusing on business continuity, corporate transparency and leadership transition for board and mangement. Retrieved January 16, 2012, from http://www.mahindrasatyam.com/media/pr5jan09.asp

Seeger, M. W. (1997). Ethics and organizational communication. Creeskill, NJ: Hampton.

Seeger, M. W., Sellnow, T. L., \& Ulmer, R. R. (2003). Communication and organizational crisis. Westport, CT: Praeger.

Seeger, M. W. \& Ulmer, R. R. (2001). Virtuous responses to organizational crisis: Aaron Feuerstein and Milt Cole. Journal of Business Ethics, 31(4), 369-376. http://dx.doi.org/10.1023/A:1010759319845

Seeger, M. W. \& Ulmer, R. R. (2003). Explaining Enron: Communication and responsible leadership. Management Communication Quarterly, 17(1), 58-84. http://dx.doi.org/10.1177/0893318903253436

Schultz, F., Kleinnijenhuis, J., Oegema, D., Utz, S., \& Van Atteveldt, W. (2012). Strategic framing in the BP crisis. A semantic network analysis of associative frames. Public Relations Review, 38, 97-107. http://dx.doi.org/10.1016/j.pubrev.2011.08.003

Sheth, N., Range, J., \& Anand, G. (2009, January 8). Cooked books for years, Satyam head quits. New York Times. Retrieved January 5, 2011, from Lexis Nexis Academic.

Silver, D. (2005, Winter). Creating transparency for public companies: The convergence of PR and IR in the post-Sarbanes-Oxley marketplace. The Public Relations Strategist, 16-19.

Small, W. (1991). Exxon Valdes: How to spend billions and still get a black eye. Public Relations Review, 17, 9-26. http://dx.doi.org/10.1016/0363-8111(91)90003-4

Stohl, M., Stohl, C., \& Townsley, N. C. (2007). A new generation of global corporate social responsibility. In S. May, G. Cheney, \& J. Roper (Eds.), Debate over corporate social responsibility (pp. 30-44). Cary, NC: Oxford University Press.

Stoker, K., \& Rawlins, B. (2005). The 'light' of publicity in the progressive era: From searchlight to flashlight. Journalism History, 30, 177-188.

The White House. (2010, May 27). Deepwater BP Oil Spill: Presidential Press Conference. Retrieved January 5, 2013 , from http://www.whitehouse.gov/photos-and-video/video/deepwater-bp-oil-spill-presidential-press-conference

Tony Hayward says BP was 'not prepared' for the Gulf oil spill. (2010, November 8). BBC News. Retrieved February 8, 2012, from http://www.bbc.co.uk/news/business-11709027

Ulmer, R. (2001). Effective crisis management through established stakeholder relationships. Management Communication Quarterly, 14(4), 590-615. http://dx.doi.org/10.1177/0893318901144003

Ulmer, R. R., Sellnow, T. L., \& Seeger, M. W. (2007). Effective crisis communication: Moving from crisis to opportunity. Thousand Oaks, CA: Sage Publications.

Webb, T. (2010, May 14). BP boss admits job on the line over Gulf oil spill. The Guardian. Retrieved February 8, 2011, from http://www.guardian.co.uk/business/2010/may/13/bp-boss-admits-mistakes-gulf-oil-spill

Williams, D. E., \& Treadaway, G. (1992). Exxon and the Valdez accident: A failure in crisis communication. Communication Studies, 43(1), 56-63. http://dx.doi.org/10.1080/10510979209368359

Yin, R. K. (2009). Case study research: Design and methods. Thousand Oaks, CA: Sage.

\section{Copyrights}

Copyright for this article is retained by the author(s), with first publication rights granted to the journal.

This is an open-access article distributed under the terms and conditions of the Creative Commons Attribution license (http://creativecommons.org/licenses/by/3.0/). 